\title{
Incentives for and Protection of Cultural Expression: Art, Trade and Geographical Indications
}

Citation for published version (APA):

Kamperman Sanders, A. W. J. (2010). Incentives for and Protection of Cultural Expression: Art, Trade and Geographical Indications. The Journal of World Intellectual Property, 13(2), 81-93.

https://doi.org/10.1111/j.1747-1796.2009.00382.x

Document status and date:

Published: 01/01/2010

DOI:

10.1111/j.1747-1796.2009.00382.x

Document Version:

Publisher's PDF, also known as Version of record

Document license:

Taverne

Please check the document version of this publication:

- A submitted manuscript is the version of the article upon submission and before peer-review. There can be important differences between the submitted version and the official published version of record.

People interested in the research are advised to contact the author for the final version of the publication, or visit the DOI to the publisher's website.

- The final author version and the galley proof are versions of the publication after peer review.

- The final published version features the final layout of the paper including the volume, issue and page numbers.

Link to publication

\footnotetext{
General rights rights.

- You may freely distribute the URL identifying the publication in the public portal. please follow below link for the End User Agreement:

www.umlib.nl/taverne-license

Take down policy

If you believe that this document breaches copyright please contact us at:

repository@maastrichtuniversity.nl

providing details and we will investigate your claim.
}

Copyright and moral rights for the publications made accessible in the public portal are retained by the authors and/or other copyright owners and it is a condition of accessing publications that users recognise and abide by the legal requirements associated with these

- Users may download and print one copy of any publication from the public portal for the purpose of private study or research.

- You may not further distribute the material or use it for any profit-making activity or commercial gain

If the publication is distributed under the terms of Article $25 \mathrm{fa}$ of the Dutch Copyright Act, indicated by the "Taverne" license above, 


\title{
Incentives for and Protection of Cultural Expression: Art, Trade and Geographical Indications
}

\author{
Anselm Kamperman Sanders
}

Maastricht University

\begin{abstract}
After the adoption of the Universal Declaration of Cultural Diversity, the interaction between the protection of traditional cultural expressions (TCEs) and geographical indicators (GIs) is an interesting one. The capacity of a geographical indication of origin to create a global market with local control over brand, quality and methods of production seems to make it immensely suitable for preservation of cultural diversity. Since the Agreement on Trade-Related Aspects of Intellectual Property Rights does not limit the potential causes of action for the unauthorized use of GIs, the tort of misappropriation may be applied in relation to TCEs. In order to reconcile intellectual property rights with non-Western belief systems, application of the tort of misappropriation, unjust enrichment and the remedy of restitution may make enforcement of GIs in relation to TCEs more palatable than other forms of protection.
\end{abstract}

Keywords geographical indications; culture; unfair competition; misappropriation

In the Preamble of the 2001 Universal Declaration of Cultural Diversity (UNESCO Convention), the United Nations Educational, Scientific and Cultural Organization (UNESCO) defined the concept of culture as follows:

Culture should be regarded as the set of distinctive spiritual, material, intellectual and emotional features of society or a social group, and that it encompasses, in addition to art and literature, lifestyles, ways of living together, value systems, traditions and beliefs (UNESCO, 2001, Preamble, fn. 2).

The UNESCO Convention entered into force on 18 March 2007 and provides a framework for states to engage in protective measures to safeguard the diversity of cultural expressions against the influences of globalization and free trade.

Trade in cultural expressions is of prime importance for cultural industries that wish to export products embodying cultural expression freely across the globe, yet many states wish to reduce the influence of foreign culture and rather stimulate their own. To that end, many countries have in place, legitimately or not (Van den Bossche, 2007), systems to protect predominantly domestic cultural values against the onslaught of popular cultural goods and services, such as Hollywood movies, books, television programmes, musical recordings, video games and online content. These systems comprise direct subsidies, ${ }^{1}$ import restrictions, tax rebates, screen quotas, ${ }^{2}$ licensing restrictions, price fixing, limits on foreign investment and foreign 
ownership, nationality requirements, domestic content requirements and intellectual property protection. Striking in this respect is the practice of siphoning off a percentage of the revenue of mandatory collecting rights societies for domestic artists and production. Copyright holders, foreign or domestic, will not receive the full proceeds of the secondary use rights of their works, but the collecting rights society rather acts as an organizer or sponsor of domestic cultural events, or "financial coach" of individual members. ${ }^{3}$

Unlike the protective measures for the protection of cultural expression described above, this contribution will discuss more free trade-oriented methods of stimulating and protecting localized art and cultural expression by means of the intellectual property system. The focus is on the use of geographical indications (GIs) to create a differentiated market for cultural expressions with localized characteristics and on the possibilities available under the Agreement on Trade-Related Aspects of Intellectual Property Rights (TRIPS Agreement) and Paris Convention for the Protection of Industrial Property (Paris Convention) ${ }^{4}$ to use unfair competition law as a means to augment a GI-type protection for traditional knowledge and cultural expressions with the doctrinal basis to act against misappropriation.

\section{Gls as a Model for Protecting Cultural Expressions?}

Most commonly associated with wines, cheeses and other agricultural products, GIs are known to be powerful marketing tools that enable consumers to differentiate between goods and make rational choices about price, quality and product characteristics (Akerlof, 1970). GIs may indicate a country, region, locality, city, or even an address from which a product or service emanates. Like a trademark, GIs are signs whose function (Maniatis and Kamperman Sanders, 1993) is to provide information and protect its owner. GIs indicate the precise geographical origin and denote a quality or reputation that results from that place of origin of a product. According to Kretschmer (2003), GIs are eminently suitable for citizens from developing nations to experiment individually or collectively with accessing global markets. Asserting one's position on a global market through branding encapsulating local products and its associated knowledge on production and cultural expression may lead to selfdiscovery and a restatement and even preservation of traditions. The creation of value in the minds of those expressing culture and in the marketplace is conducive to the protection of cultural diversity, as market differentiation, even in purely economic terms, increases consumer welfare. Its abilities to engender collective stakeholdership, the connection to a certain place or locality, and differentiating characteristics, make GIs eminently suitable to play a role in the protection, not only of a market in traditional cultural expressions (TCEs), but also of TCEs and cultural diversity itself.

In spite of the fact that the international definition of what exactly constitutes a GI is not uniform, the question whether TCEs can be protected by GIs has been convincingly answered affirmatively by Zografos (2006). The Paris Convention covers two notions of GIs: "indications of source or appellations of origin", 5 which 
are further defined by the Madrid Agreement for Repression of False and Deceptive Indications of Source of Goods (Madrid Agreement) ${ }^{6}$ and the Lisbon Agreement for the Protection of Appellations of Origin and their International Registration (Lisbon Agreement). It is of importance to realize that the notion of "appellation" covers names, whereas "indication" also comprises drawings, photos, national emblems, flags or even symbolism.

The Madrid Agreement indicates that "indications of source" denote that a product or service originates from a certain area, country, region or locality. According to the Lisbon Agreement, "appellation of origin" covers a "geographical name of a country, region, or locality, which serves to designate a product originating therein, the quality and characteristics of which are due exclusively or essentially to the geographical environment, including natural and human factors". ${ }^{7}$

In the European Union (EU), GIs are protected on the basis of Council Regulation $510 / 2006 / \mathrm{EC}^{8}{ }^{8}$ which offers protection to GIs of agricultural products and foodstuffs. ${ }^{9}$ It employs other definitions. Whereas the definition of designation of origin ${ }^{10}$ corresponds largely with those of the Lisbon Agreement, the definition of "geographical indication" 11 raises the threshold for appellations of origin.

The TRIPS Agreement has yet another definition in article 22, which defines GIs as "indications which identify a good as originating in the territory of a member, or locality in that territory, where a given quality, reputation or other characteristic of the good is essentially attributable to its geographic origin". Although similar to the definition in the Council Regulation, the notion of "indication" is wider than that of "name", and its overall scope is somewhat wider (Gervais, 1998, pp. 123-5; Stewart, 1993). The crucial aspect of the definition of GIs in the TRIPS Agreement is the requirement that the goods to be covered have a quality or characteristic that derives from the place of origin and cannot have been derived from another place.

Whatever the definition in various international agreements, however, it is clear that within the context of the TRIPS Agreement, GIs can be used for price discrimination, but also for the bundling of local knowledge through a localized organization of producers. Unlike a trademark, which can be transferred freely, irrespective of the locality in which production takes place, the link between the product and its geographical origin furthermore ensures that the geographical indication is tied to a locality and controlled locally.

The TRIPS Agreement does not specify by which method World Trade Organization (WTO) members have to protect GIs. This can be done through a sui generis GI protection regime, or through use of trademark and certification marks. Trade and certification mark systems can be relied upon for applications, registrations, oppositions, cancellations, adjudication and enforcement through national trademark regimes (Bengedkey and Mead, 1992; McCarthy, 1998-2009, pp. 19-32; Pollack, 1962). A system like this meets the requirements for national treatment and TRIPS Agreement enforcement requirements in tandem with the national trademark regime. The disadvantage, however, is clear to see. Although 
such multiple registration may not be a problem for strong entities or regions which have considerable economic power, ${ }^{12}$ smaller and poorer regions or municipalities may have greater difficulty and the cost of undertaking the task of registering in numerous countries.

The system of protection by means of a sui generis GI system is different in nature. GIs are territorial in the sense that they are recognized in and by the jurisdiction where the area or locality lies that they are related to. The feature of territoriality is both its strength and its weakness. Legal protection is granted in a local territory, but like any IP right, it is territorial and confined to its national jurisdiction. International conventions are commonly used to remedy this territorial feature. The key idea is that once a GI is recognized by the government in one country, other members to an international agreement will recognize the right in the GI too. The scope of protection for GIs found in the TRIPS Agreement encompasses two levels of protection that tailor for the protection of GIs as indicators of consistent quality and an enhanced protection enabling product differentiation (Kamperman Sanders, 2005). The aforementioned local control on a territorial connection explains why at the fifth session of the World Intellectual Property Organization (WIPO) Intergovernmental Committee on Intellectual Property and Genetic Resources, Traditional Knowledge and Folklore, ${ }^{13}$ the point was made that TCE's that can be qualified as goods, such as handicraft items, can also be protected by GIs. In this instance, a GI can be affixed to a product that is made from natural resources or through knowledge held by an indigenous group. Furthermore, some TCEs consisting of names, signs or other indications can themselves serve as GIs. It is then interesting to look at the scope of protection that GIs enjoy.

\section{Integrity of Information}

The prohibited acts described in article 22(2) of the TRIPS Agreement encompass misleading use of GIs "by any means in the designation or presentation of a good that indicated that the good in question originates in a geographical area other than the true place of origin" and acts of unfair competition as defined under article 10bis of the Paris Convention. ${ }^{14}$ Through this provision, article 22(2) not only covers misleading allusions to or connotations of origin by use of both words and graphics, but also covers the use of a GI on goods of low(er) quality emanating from the proper geographical area. Article 22(4) extends this protection to a case of use of GIs that, although correct, do not correspond with the geographical indication commonly understood to produce the goods with the special qualities in question, or although factually correct do not correspond with consumer expectations about origin and quality. Usually this situation arises in those cases where the same name exists in different territories, or when a description is used that is likely to confuse the consumer as to the geographical area from which the product is commonly understood to come from, like: "Parma cheese produced in America" (Baeumer, 1999, p. 17). 
Article 22(2) protection is designed to safeguard that the consumer receives accurate information that enables him to differentiate between products emanating from the designated area from substitute products from outside the designated area. As indicators of quality, GIs provide information that help consumers make choices and reduce risk, or differently put: "If he [the consumer] is interested in origin, it is normally because origin imports an expectation about some quality" (Cornish and Phillips, 1982, p. 43). When the integrity of this information is tampered with, so as to render it incomplete or deceptive, this leads to market failure and welfare loss. Akerlof (1970) succinctly depicts the breakdown in the market when the consumer cannot trust the information about the product he wishes to purchase. The consumer will then prefer to buy goods of lower quality until-as in a vicious circle - the only goods available will be those of the lowest quality. Article 22(2) and 22(4) therefore also leans against allusions to a geographical indication or connotations in writing and image that distort the conveyance of correct information.

The inclusion of actions against unfair competition under article 10bis of the Paris Convention in GIs protection, however, means that the potential scope of protection is not limited to confusion, but also extends to concepts such as dilution, the depreciation of goodwill or reputation, or even attempts to derive an undeserved benefit from a GI. The doctrine of unfair competition may be internationally recognized by its inclusion in article 10bis of the Paris Convention, but a national comparison shows a wide diversity of forms of implementation (Kamperman Sanders, 1997; Ohly, 1995; de Very, 2005) albeit all with the aim to strike a balance between fairness and freedom in competition. It is this general and elastic principle that provides the courts with the possibility to award protection to the fruits of someone's ingenuity, skill, or labour on a case-by-case basis. This need for elasticity means that it is not possible to encapsulate all unfair acts in statutory provisions (Sell, 1958). Two main approaches for giving effect to the obligations of article 10bis of the Paris Convention can be discerned, namely protection on the basis of general provisions in a civil code, or enacted legislation on unfair competition (WIPO, 1994). Despite all examples of unfair behaviour provided for by article 10bis of the Paris Convention itself, or national legislation, there is always a residual category of "unfair commercial practices" that may be covered by a general clause. Here judges have to draw the line between what is fair and unfair in the marketplace (Ohly, 1995). The United Kingdom, however, has chosen to give effect to the obligations of the Paris Convention in relation to specific heads of interest under the law of passing off, injurious falsehood, or trade secrets only (Graf von Westerholt and Gysenberg, 1981), rather than "under a wide generalisation". ${ }^{15}$ Still, once a specific head of interest can be defined, the law of passing off has shown to be flexible as well (Wadlow, 1995). In defining a head of interest for the protection of TCEs, however, one has to be conscious of the fact that indigenous peoples may have a different value system and often regard traditional knowledge and cultural heritage as "deeply personal and spiritual", a resource not subject to exploitation and misappropriation (Conway-Jones, 2005, p. 3). In the context of article 10bis of the Paris Convention, the concept of protection of misappropriation is 
also present. It is not clearly exemplified, but is nevertheless capable of offering a protective measure against the usurpation of intellectual assets that may be considered as the property or quasi-property of another (Kamperman Sanders, 1997). In this respect, the concept of misappropriation can be used to prevent someone from passing off one's own goods as those from someone else (Cornish and Llewelyn, 2003, pp. 593 et seq.), but also from "reaping where he has not sown" in the sense of the landmark case International News Service v Associated Press. ${ }^{16}$ This is not so much a form of assertion of an exclusive right of property, but the protection against usurpation or unjust enrichment (Callmann, 1942). When tied to and limited by geographical factors, such as land and human involvement, unjust enrichment may just be enough to create head of interest that merits protection for TCEs. If one limits the remedy for unjust enrichment to restitution of what one has gained at the expense of another, the scope of protection against misappropriation of TCEs will furthermore not be overbroad.

\section{Product Differentiation}

Article 23 of the TRIPS Agreement is limited in application to wines and spirits, but offers a wider scope of protection. There is no need for the consumer to be misled or proof that certain behaviour constitutes an act of unfair competition. The burden of proof is not as high. For wines and spirits this additional protection translates into the possibility to protect GIs even when the consumer is not confused. A prohibition of use of expressions such as "kind", "type" or "style" in relation to a GI reflects that the purpose for the protection lies in the safeguarding of a particular production technique or product characteristic and may even be used to protect a GI against the dilution of a reputation for superior quality. As such, article 23 protection may be used to facilitate product differentiation and would ideally enable producers in a designated geographical area to set higher prices, produce more, and preserve those traditional methods of production and levels of high quality that result from sustained investment, enable start-up industries to develop innovative production techniques, or enable producers to make the transformation from local to global markets.

Still, it is important to realize that there are limitations to article 23 protection. Through article 24(4), existing use of a GI is preserved and generic terms are excluded from protection. Apart from formal limitations there is also a real-life limitation in economic terms. For a GI to derive real benefit from this level of enhanced protection, investment in advertising and marketing is a must. Reputation needs time to develop. In this respect, some authors (Hausman and Rodrik, 2002) emphasize that the key to economic development is learning what one is good at producing.

\section{Traditional Knowledge and Cultural Expressions}

At an international level, the discussion on extending the protection of GIs to encompass traditional knowledge and cultural expressions has predominantly 
focused on biopiracy issues and the protection of genetic resources (Rafi Communique, 1994). Protection of traditional cultural expressions is, however, also part of the ongoing discussion in the context of the so-called development agenda at WIPO and the TRIPS Agreement discussions at the WTO (Kamperman Sanders, 2005; 2007). Although the discussion on these issues is often conducted in parallel, it is clear that different forms of protection for traditional knowledge need to be considered (Correa, 2001). Concerns over biopiracy, misappropriation of genetic resources and benefit sharing arrangements demand measures in the regulatory sphere of sovereignty and public international law. ${ }^{17}$ Protection of cultural expressions calls for different measures, a private property IP regime that is shaped by local mores, endorsed by the state, recognized internationally, and one which provides incentives for innovative approaches to preservation and marketing of traditional knowledge and culture. The question then is whether to do this through sui generis systems or through traditional IP tools. It is here that developed and developing countries do not see eye to eye. ${ }^{18}$

Intellectual property law is commonly designed to provide incentives to create, rather than to preserve. For traditional cultural expressions, this means that a supportive legal regime should not exclusively focus on the act of creation. Finding novel ways of expressing traditional culture is an act of creation in and by itself, but this is different to the fostering of innovative approaches to preservation, and marketing of traditional knowledge and culture is more related to marketing and channelling revenues into traditional modes of production (Weeraworawit, 2003, p. 159). It is here that a system akin to those protecting GIs may be considered for the protection of TCEs. GIs are sustainable over a long period of time, even into perpetuity for as long as a particular method of production is maintained. A GI is also not reliant on concepts such as novelty or originality, like patent or copyright systems are. As such a GI would seem ideally suited as an example for the protection of traditional knowledge and cultural expressions. GIs serve to instil value in a sign that encapsulates locally produced goods containing unique geographical ingredients or produced with localized human knowledge. Protecting TCEs as GIs may not protect the knowledge encapsulated in the product per se, in fact the knowledge remains in the public domain. However, an entitlement is created that permits the holders of the right to protect not only a sign, but also a connection with or even paternity to the product that is the TCE. This is where the aforementioned concept of misappropriation may play an important role, so in the next section some practical examples will be provided. First, however, the issue of recognition of TCEs as GIs has to be further explored.

\section{Qualifying for Protection}

The issue of recognition domestically and internationally is a hotly contested issue in the area of standard GIs, so this issue will also be of concern for protection of TCEs. In essence all IP rights are territorial and it would be up to 
the nation state to decide whether "Cultural Expressions" would be recognized and what the criteria are. Then international protection would have to be ensured. In 2005, the EU submitted a proposal under the Doha Round at the WTO on a multilateral register for GIs, introducing a legally binding system requiring member states to report their GIs to the WTO. This multilateral register would also have to cover agricultural products and handicrafts. Recently, during the WTO Trade Negotiations Committee meetings in May and June 2008, ${ }^{19}$ this proposal was modified to entail a register in which GI holders can publish their GIs multilaterally for notification, but would have to go through the national register of each country to obtain legal protection. The WTO registration would have the purpose of providing evidence of the claim to the GI. Most notably, this would be that the indication is not generic, for if it is, it must be excluded from protection under articles 22 and 23 of the TRIPS Agreement. Once the GI, or for that matter a "Cultural Expression", is notified to the WTO, this could lead to protection in other member states, either through an automatic recognition (like in the Lisbon Agreement system), or through a national recognition of the WTO notification.

Which TCEs should, however, qualify for protection? The combined rationale for protection of GIs, traditional knowledge and cultural expression already provides an indication for the type of requirements that should be used by national governments in order to describe which products or productions fall within the protected category, just like Parma Ham, Champagne, or Port wine, the method of production, or the form of the cultural expression. If one only looks at India one can think of folk dances like Bhangra of the Punjab, Bihu of Assam etc., or theatre like the oldest surviving theatre traditions of the world, the 2000-year-old Kutiyattam of Kerala. The advantage of a GI-type system is clear to see. Since there is no prohibition against using the Kutiyattam itself as inspiration for new development in theatre, there would be a prohibition against using the term Kutiyattam in relation to theatre that does not adhere to the prescribed "ingredients" of a Kutiyattam play. Not to be allowed to use the component parts (story line, narrative, characters, symbolism, music) of Kutiyattam would go too far for a Westerner placing value on progress and innovation. According to WIPO (2001, p. 25), traditional knowledge includes "tradition based literary, artistic and scientific works, performances, inventions, scientific discoveries, designs, marks, names and symbols, undisclosed information and all other tradition-based innovations and creations resulting from intellectual activity in the industrial, scientific, literary or artistic field". Yet when it comes to traditional knowledge, holistic notions of knowledge and indigenous expressions often sit uneasy with the liberties that modern business takes with what indigenous peoples perceive to be sacred (Antons, 2005). It is in this context that the concept of misappropriation is useful. If, for example, Maori patterns are used for tattoos of persons who have not earned the tribal right to wear them, both the tattoo artist and the wearer have misappropriated the imagery (Gray, 2005). 
The remedies for misappropriation of TCEs can mostly be restitutional. Any benefit that has passed from the claimant to the enriched must then be restored. Admittedly, given the more or less permanent nature of the tattoo, this example presents problems. Financial compensation may be in order if corrective tattooing or laser-removal treatment is not deemed appropriate. In other cases of misappropriation, however, handing over infringing goods and corrections in the media may be sufficient.

\section{Conclusion}

In a globalizing world the preservation of cultural diversity has become a prime concern. Intellectual property rights, traditionally used to foster innovation, can also be used for the purpose of preservation. A GI-type protection for traditional knowledge and cultural expressions with the doctrinal basis to act against misappropriation may offer a way forward in reconciling local traditional knowledge and belief systems with Western notions of property.

\section{About the Author}

Anselm Kamperman Sanders, is a Professor of Law and Director of the Masters Intellectual Property Law and Knowledge Management (LLM/MSc) at Maastricht University, the Netherlands, and Academic Director IEEM Intellectual Property Law School, Macau SAR, China; e-mail: a.kampermansanders@pr.unimaas.nl

\section{Notes}

1 For Europe, Eurimages fund, Council of Europe, Resolution (88) 15 of 16 October 1988, Media Plus, Decision 2000/821/EC of the Council of 20 December 2000 on Media Plus - development, distribution and promotion; and Decisions 613/2001/EC of the European Parliament and the Council of 19 January 2001 on MEDIA training. For Canada, see the Department of Canadian Heritage website for a number of measures benefitting Canadian publishers and music, film, and multimedia producers [online]. Available at $\langle$ http://www.pch.gc.ca $\rangle$ [Accessed July 2009].

2 See, for example, the quota system for foreign broadcasts in the Television Without Frontiers Directive 89/552/EEC, which was adopted in 1989, revised in 1997 by Directive 97/36/EC and in 2007 to become the Audiovisual Media Services Directive 2007/65/EC.

3 See, for example, the website of BUMA/Stemra, a Dutch collecting society for music [online]. Available at $\langle$ http://www.bumastemra.nl $\rangle$ [Accessed July 2009]. The society runs a social fund that provides loans, donations, pension plans and insurance for individual music authors who are members and a cultural fund that promotes Dutch music as a product by organizing, financing and subsidizing numerous events nationally and internationally. Similar arrangements are available for authors, performing artists, music publishers, producers and distributors of music, film and interactive software, photographers, editors, translators, etc. 
4 Paris Convention for the Protection of Industrial Property of 20 March 1883, as revised at Brussels, 1900, Washington, 1911, The Hague, 1925, London, 1934, Lisbon, 1958, and Stockholm, 1967, and as amended on 2 October 1979.

5 Article 10 of the Paris Convention, on False Indications of Source of Goods.

6 Madrid Agreement for the Repression of False or Deceptive Indications of Source on Goods of 14 April 1891, as revised at Washington 1911, The Hague, 1925, London, 1934, and Lisbon, 1958.

7 Article 2 of the Lisbon Agreement for the Protection of Appellations of Origin and their International Registration of 31 October 1958, as revised at Stockholm, 1967, and as amended on 28 September 1979.

8 Replacing Regulation 2081/92/EEC, as amended by Council Regulation 692/2003.

9 Regulation 510/2006/EC of 20 March 2006 on the protection of geographical indications and designations of origin for agricultural products and foodstuffs was implemented following the WTO panel reports in United States (WT/DS174) and Australia (WT/DS290), adopted by the DSB on 20 April 2005. The new Regulation extends the protection available for EU geographical indications to foreign geographical indications, without requiring an equivalent and reciprocal level of protection offered to EU geographical indications by the foreign government. Non-EU producers wishing to apply for protection of their geographical indication may furthermore apply directly to the commission, rather than having to address their own national government.

10 Regulation 2081/92/EEC, article 2(2)(a) designation of origin means the name of a region, a specific place or, in exceptional cases, a country, used to describe an agricultural product or a foodstuff:

- originating in that region, specific place or country and

- the quality or characteristics of which are essentially or exclusively due to a particular geographical environment with its inherent natural and human factors, and the production, processing and preparation of which take place in the defined geographical area.

11 Regulation 2081/92/EEC, article 2(2)(b) geographical indication means the name of a region, a specific place or, in exceptional cases, a country, used to describe an agricultural product or a foodstuff:

- originating in that region, specific place or country and

- which possesses a specific quality, reputation or other characteristics attributable to that geographical origin and the production and/or processing and/or preparation of which take place in the defined geographical area.

12 Vide Champagne or Roquefort.

13 See Document WIPO/GR TKF/IC/5/3, 52.

14 Paris Convention, article 10bis-Unfair Competition

(1) The countries of the Union are bound to assure to nationals of such countries effective protection against unfair competition.

(2) Any act of competition contrary to honest practices in industrial or commercial matters constitutes an act of unfair competition.

(3) The following in particular shall be prohibited:

1. all acts of such a nature as to create confusion by any means whatever with the establishment, the goods, or the industrial or commercial activities, of a competitor; 
2. false allegations in the course of trade of such a nature as to discredit the establishment, the goods, or the industrial or commercial activities, of a competitor; 3. indications or allegations the use of which in the course of trade is liable to mislead the public as to the nature, the manufacturing process, the characteristics, the suitability for their purpose, or the quantity, of the goods.

15 Victoria Park Racing and Recreation Grounds Co. v Taylor (1937) 58 CLR 479; see in this respect also Mogul Steamship Co. v McGregor Gow \& Co. (1889) 23 QBD 598 at 625-6; and Hodgkinson \& Corby Ltd and Roho Inc. $v$ Wards Mobility Services Ltd (1995) FSR 169 per Jacob J.: "There is no tort of copying. There is no tort of taking a man's market or customers. Neither the market nor the customers are the plaintiff's to own. There is no tort of making use of another's goodwill as such. There is no tort of competition".

16248 US 215 (1918).

17 For a repository of articles on this issue see the website available at 〈http:// www. iprsonline.org/resources/tk.htm $\rangle$ [Accessed July 2009].

18 See country positions submitted to the 11th Inter Governmental Conference (IGC) meeting held from 3 to 12 July 2007 in Geneva at the WIPO.

19 See Document TN/C/W/52 of 19 July 2008, available from documents online at $\langle$ http:// www.wto.org [Accessed July 2009].

\section{References}

Akerlof, G. (1970) 'The Market for "Lemons": Quality Uncertainty and the Market Mechanism', Quarterly Journal of Economics, 84(3), 488-500.

Antons, C. (2005) 'Traditional Knowledge and Intellectual Property Rights in Australia and Southeast Asia', in C. Heath and A. Kamperman Sanders (eds.), New Frontiers of Intellectual Property Law. Hart Publishing, Oxford, pp. 37-52.

Baeumer, L. (1999) 'Protection of Geographical Indications under WIPO Treaties and Questions Concerning the Relationship between those Treaties and the TRIPS Agreement' in 'Symposium on the Protection of Geographical Indications in the Worldwide Context', WIPO publication No. 760(E), proceedings of symposium held in WIPO, Geneva, Egez, Hungary, 23-25 October 1997.

Bengedkey, L. and Mead, C. (1992) 'International Protection of Appellations of Origin and Other Geographical Designations of Regional Origin Under the Lanham Act', Trademark Reporter, 82, 765-792.

Callmann, R. (1942) 'He Who Reaps Where He Has Not Sown: Unjust Enrichment in the Law of Unfair Competition', Harvard Law Review, 55, 595-614.

Conway-Jones, D. (2005) 'Safeguarding Hawaiian Traditional Knowledge and Cultural Heritage: Supporting the Right to Self-determination and Preventing the Commodification of Culture', Howard Law Journal, 48, 737-762.

Cornish, W. and Llewelyn, D. (2003) Intellectual Property: Patent, Copyright, Trade Marks and Allied Rights, 5th edition. Thomson Sweet \& Maxwell, London.

Cornish, W. and Phillips, J. (1982) 'The Economic Function of Trade Marks: An Analysis with Special Reference to Developing Countries', International Review of Industrial Property and Copyright Law, 13, 41-64.

Correa, C. (2001) Traditional Knowledge and Intellectual Property-Issues and Options Surrounding the Protection of Traditional Knowledge [online]. QUNO. Available at 
〈http://www.quno.org/geneva/pdf/economic/Discussion/Traditional-Knowledge-IPEnglish.pdf $\rangle$ [Accessed April 2009].

de Very, R. (2005) Towards a European Unfair Competition Law. Koninklijke Brill, Leiden. Gervais, D. (1998) The TRIPS Agreement. Drafting History and Analysis. Sweet \& Maxwell, London.

Graf von Westerholt, H. and Gysenberg, H. (1981) 'Vereinigtes Königreich von Großbritannien und Nordirland, Part VI, in E. Ulmer (ed.), Das Recht des unlauteren Wettbewerbs in den Mitgliedstaaten der EWG. Carl Heymanns Verlag, Köln.

Gray, E. (2005) 'Maori Culture and Trade Mark Law in New Zealand', in C. Heath and A. Kamperman Sanders (eds.), New Frontiers of Intellectual Property Law. Hart Publishing, Oxford, pp. 71-96.

Hausman, R. and Rodrik, D. (2002) 'Economic Development As Self-Discovery', National Bureau of Economic Research Working Paper 8952 [online]. Available at $\langle$ http:// ksghome.harvard.edu/ .drodrik.academic.ksg/papers.html $\rangle$ [Accessed April 2009]

Kamperman Sanders, A. (1997) Unfair Competition Law-The Protection of Intellectual and Industrial Creativity. Clarendon Press, Oxford.

Kamperman Sanders, A. (2005) 'Future Solutions for Protecting Geographical Indications Worldwide', in C. Heath and A. Kamperman Sanders (eds.), New Frontiers of Intellectual Property Law. Hart Publishing, Oxford, pp. 133-48.

Kamperman Sanders, A. (2007) 'The Development Agenda for Intellectual Property', in C. Heath and A. Kamperman Sanders (eds.), Intellectual Property and Free Trade Agreements. Hart Publishing, Oxford, pp. 3-26.

Kretschmer, M. (2003) 'The Economics of Geographical Indications', in 'Queen Mary and Fordham University NY Joint Seminar Series', proceedings of a conference held in Barbican, London, November 2003 (unpublished).

Maniatis, S. M. and Kamperman Sanders, A. (1993) 'A Consumer Trade Mark: Protection based on Origin and Quality', European Intellectual Property Review, 11, 406-415.

McCarthy, J. (1998-2009) McCarthy on Trademarks and Unfair Competition, 4th edition. West Publishing, New York.

Ohly, A. (1995) Richterrecht und Generalklausel im Recht des unlauteren Wettbewerbs. Carl Heymanns Verlag, Köln.

Pollack, L. (1962) 'Roquefort-An Example of Multiple Protection for a Designation of Regional Origin Under the Lanham Act', Trademark Reporter, 52, 755-67.

Rafi Communique (1994), 'Bioprospecting-Biopiracy and Indigenous Peoples' [online], November. Available at $\langle$ http://www.rafiusa.org $\rangle$ [Accessed July 2009].

Sell, E. (1958) 'The Doctrine of Misappropriation in Unfair Competition. The Associate Press Doctrine after Forty Years', Vanderbilt Law Review, 11, 483-500.

Stewart, T. (1993) The GATT Uruguay Round, A Negotiating History. Kluwer Law International, The Hague.

United Nations Educational, Scientific and Cultural Organization (2001) Universal Declaration on Cultural Diversity. Available at $\langle$ http://www.unesco.org $\rangle$ [Accessed July 2009].

van den Bossche, P. (2007) Free Trade and Culture: A Study of Relevant WTO Rules and Constraints on National Cultural Policy Measures. Boekmanstudies, Amsterdam. Wadlow, C. (1995) The Law of Passing-off. Sweet and Maxwell, London. 
Weeraworawit, W. (2003) 'International Legal Protection for Genetic Resources, Traditional Knowledge and Folklore: Challenges for the Intellectual Property System', in C.

Bellmann, G. Dutfield and R. Meléndez-Ortiz (eds.), Trading In Knowledge:

Development Perspectives on Trips, Trade and Sustainability. Earthscan Publications, London, pp. 157-65.

World Intellectual Property Organization (1994) Protection against Unfair Competition. World Intellectual Property Organization, Geneva.

World Intellectual Property Organization (2001) Report on Fact-Finding Missions on Intellectual Property and Traditional Knowledge. World Intellectual Property Organization, Geneva.

Zografos, D. (2006) 'Can Geographical Indications be a Viable Alternative for the Protection of Traditional Cultural Expressions?', in F. Macmillan and K. Bowrey (eds.), New Directions in Copyright Law, Vol. 3, Edward Elgar, Cheltenham, pp. 37-55. 